\title{
Study of the organization of the genomes of Escherichia coli, Brucella melitensis and Agrobacterium tumefaciens by insertion of a unique restriction site
}

\author{
Estelle Jumas-Bilak, ${ }^{1}$ Claude Maugard, ${ }^{1}$ Sylvie Michaux-Charachon, ${ }^{1}$ \\ Annick Allardet-Servent, ${ }^{1}$ Arnaud Perrin, ${ }^{2}$ David $O^{\prime}$ Callaghan ${ }^{1}$ and \\ Michel Ramuz ${ }^{1}$
}

Author for correspondence: Estelle Jumas-Bilak. Tel: +33662346 79. Fax : +3366236652.

\footnotetext{
1 Institut National de la Santé et de la Recherche Médicale, Unité 431, Faculté de Médecine, Avenue Kennedy, 30900 Nîmes, France

2 Unité de Génétique Moléculaire des Levures, Institut Pasteur, 25 rue du Dr Roux, 75724 Paris Cedex 15, France
}

\begin{abstract}
Tn5Map, a Tn5 derivative containing the 18 bp I-Scel site, was delivered from a RP4-mobilizable, RK6-derived suicide vector to Escherichia coli HB101, Brucella melitensis and Agrobacterium tumefaciens C58, which all lack natural I-Scel sites in their genomes. Digestion of the DNA from Tn5Map-containing strains and analysis by pulsed-field gel electrophoresis (PFGE) revealed that these derivatives contained a single transposon insertion. These digests also gave direct and independent proof for the single circular chromosome of $E$. coli, and for the presence of two circular chromosomes in B. melitensis and of a circular and a linear chromosome in A. tumefaciens C58 (which also contains two large circular plasmids). This rapid and versatile technique is potentially applicable to the study of the genomic organization in all Gram-negative bacteria which support Tn5 transposition. Moreover, linearization of circular replicons could be the first step for a rapid method of physical mapping.
\end{abstract}

Keywords: bacterial chromosomes, unique restriction site, genome organization, physical mapping

\section{INTRODUCTION}

The bacterial chromosome has long been considered to be a unique circular molecule. In the last 15 years, a few reports proved that this is not always the case: several bacterial species have a linear chromosome (for a review see Hinnebush \& Tilly, 1993), and others have multiple chromosomes (for a review see Cole \& Saint Girons, 1994).

The experimental determination of genome topology makes use of pulsed-field gel electrophoresis (PFGE), which allows separation of linear genome-sized DNA molecules, but not of circular DNA molecules larger than $15 \mathrm{~kb}$, which are excluded by the agarose gel. Usually a small proportion of circular DNA molecules suffer a random double-strand break during preparation and are thus linearized, producing a diagnostic faint band (Sobral et al., 1991). A much better distinction between circular and linear genomes could be made if these had an unique restriction site for specific and quantitative linearization of circular genomes or cutting linear genomes into two parts. In this paper we describe how this can be achieved by delivering a $\operatorname{Tn} 5$ derivative carrying the I-SceI restriction site. I-SceI is an endonuclease encoded by a group $\mathrm{I}$ intron of the Saccharomyces cerevisiae mitochondrial 21S rRNA gene (Monteilhet et al., 1990; Perrin et al., 1993). I-SceI recognizes, with high specificity, a non-symmetrical double-stranded sequence extending over $18 \mathrm{bp}$. In optimum conditions, no cleavage sites were found in the entire yeast nuclear genome, or in a range of bacterial genomes.

A technique combining transposon delivery using a widehost-range, conjugative, suicide plasmid vector, I-SceI digestion of genomic DNA, and PFGE, was tested on three bacterial species with known genome topology: Escherichia coli, which contains a single circular chromosome, Brucella melitensis, which possesses two circular chromosomes (Michaux et al., 1993), and Agrobacterium tumefaciens $\mathrm{C} 58$, which is believed to contain both a $3 \mathrm{Mb}$ circular and a $2 \cdot 1 \mathrm{Mb}$ linear chromosome together with two circular plasmids of 550 and $200 \mathrm{~kb}$ (Allardet-Servent et al., 1993). 


\section{METHODS}

Strains and growth conditions. Bacterial strains and plasmids are listed in Table 1. E. coli and A. tumefaciens were grown in LB medium at 37 or $28^{\circ} \mathrm{C}$ respectively. B. melitensis was grown at $37^{\circ} \mathrm{C}$ on Brucella Agar or in TSB (Gibco). When required, media were supplemented with ampicillin $\left(100 \mu \mathrm{g} \mathrm{ml}^{-1}\right)$, streptomycin $\left(100 \mu \mathrm{g} \mathrm{ml}^{-1}\right)$ and kanamycin $\left(25 \mu \mathrm{g} \mathrm{ml}^{-1}\right)$. A spontaneous streptomycin-resistant mutant of $B$. melitensis Ether was selected by plating on Brucella Agar containing streptomycin. Its agglutination, phage sensitivity, and restriction profile in PFGE were identical to those of the parental strain. Plating $A$. tumefaciens $\mathrm{C} 58$ on medium with $25 \mu \mathrm{g}$ kanamycin $\mathrm{ml}^{-1}$ gave rise to a high frequency of resistant mutants. To avoid this problem, selection of $\mathrm{Kan}^{\mathrm{R}} A$. tumefaciens transconjugants was made on medium containing $200 \mu \mathrm{g}$ kanamycin $\mathrm{ml}^{-1}$.

Recombinant DNA techniques. These were as described by Sambrook et al. (1989). Restriction endonucleases, T4 DNA ligase, and calf intestinal alkaline phosphatase were from Boehringer Mannheim or New England Biolabs and were used as recommended by the manufacturers.

Delivery of Tn5Map. pGF2 was transferred from $E$. coli SM10גpir by standard filter mating techniques. SM10גpir(pGF2) was mixed with E. coli HB101, B. melitensis Ether ${ }^{\mathrm{SmR}}$ or $A$. tumefaciens $\mathrm{C} 58$ (donor: recipient ratio $1: 5$ ) in a $5 \mathrm{ml}$ syringe and filtered onto a $0.45 \mu \mathrm{m}$ filter. The filter was transferred to an LB plate and incubated overnight. Bacteria on the filter were then recovered in $\mathrm{LB}$ and plated onto media containing streptomycin and kanamycin to select transposition events. Colonies were visible after overnight incubation ( $E$. coli) or $3 \mathrm{~d}$ (Brucella and Agrobacterium).

Endonuclease digestion of high-molecular-mass genomic DNA. Intact genomic DNA was prepared in agarose plugs as described by Schwartz et al. (1983). The cells were harvested in exponential growth. The usual DNA concentration $(1 x)$ was about $2 \mu \mathrm{g}$ per plug but $5 \times$ concentrated plugs were used when indicated. Digestions with $S_{w a I}$ and PacI were performed as previously described (Allardet-Servent et al., 1993; Michaux et al., 1993). Conditions of I-SceI digestion, defined by the manufacturer (Boehringer Mannheim), were further optimized, first following previously described indications (Thierry et al., 1991 ) and then as follows: the plugs were preincubated at $4{ }^{\circ} \mathrm{C}$ with the enzyme in the complete buffer for $100 \mathrm{~min}$, in order to allow the enzyme to diffuse, and then transferred at $37^{\circ} \mathrm{C}$ for $15 \mathrm{~min}$ for DNA digestion. Double digestions were done sequentially. The first enzyme was eliminated by overnight incubation of the plug at $37^{\circ} \mathrm{C}$ in $0.5 \mathrm{M}$ EDTA (pH 8), $1 \mathrm{mg}$ proteinase $\mathrm{K} \mathrm{ml}^{-1}$ and $1 \%(\mathrm{w} / \mathrm{v}) \mathrm{N}$-lauroyl sarcosine. Plugs were then washed twice in TE-PMSF $(10 \mathrm{mM}$ Tris $\mathrm{pH} 8$, $0 \cdot 1 \mathrm{mM}$ EDTA, $1 \mathrm{mM}$ phenylmethylsulfonyl fluoride) and three times in TE (10 mM Tris $\mathrm{pH} 8,0.1 \mathrm{mM}$ EDTA) before digestion with the second enzyme.

PFGE of intact and digested DNA. PFGE was performed in a contour-clamped homogeneous electric field apparatus (Chu et al., 1986) CHEF-DRII (Bio-Rad) in 0.5 × TBE (Sambrook et al., 1989). S. cerevisiae chromosomes (BioRad) served as size

Table 1. Strains and plasmids used in this study

\begin{tabular}{|c|c|c|}
\hline Strain & Characteristics/genotype & Source/reference \\
\hline \multicolumn{3}{|l|}{ E. coli } \\
\hline SM10ìpir & $\begin{array}{l}\text { thi thr leu ton } A \text { lacY } Y \text { supE } \\
\operatorname{rec} A:: \text { RP4-2Tc:: } \mathrm{Mu} \mathrm{Km} \lambda \text { pir }\end{array}$ & Miller \& Mekalanos (1988) \\
\hline SY327 $\lambda$ pir & $\begin{array}{l}\Delta(\text { lac-pro }) \operatorname{argE}(\mathrm{Am}) \text { rif nal } A \\
\operatorname{rec} A \lambda \text { pir }\end{array}$ & Miller \& Mekalanos (1988) \\
\hline HB101 & $\begin{array}{l}\text { bsdS } \operatorname{rec} A \text { ara pro } A \text { lac } Y \text { galK } r p s L x y l L \\
m t l \sup E\end{array}$ & Laboratory strain \\
\hline HB101 $\omega 1$ & Tn5Map in the chromosome & This study \\
\hline $\mathrm{HB} 101 \omega 2$ & Tn5Map in the chromosome & This study \\
\hline \multicolumn{3}{|c|}{ Brucella melitensis } \\
\hline Ether & Biovar 3 & ATCC 23458 \\
\hline Ether ${ }^{\mathrm{SmR}}$ & Streptomycin resistant & This study \\
\hline Ether $\omega 1^{\text {SmR }}$ & $\begin{array}{l}\text { Tn } 5 \mathrm{Map} \text { in the } 2 \cdot 2 \mathrm{Mb} \text { replicon, } \\
\text { streptomycin resistant }\end{array}$ & This study \\
\hline Ether $\omega 2^{\operatorname{SmR}}$ & $\begin{array}{l}\text { Tn } 5 \text { Map in the } 1.1 \mathrm{Mb} \text { replicon, } \\
\text { streptomycin resistant }\end{array}$ & This study \\
\hline \multicolumn{3}{|l|}{ Agrobacterium } \\
\hline \multicolumn{3}{|l|}{ tumefaciens } \\
\hline $\mathrm{C} 58$ & Streptomycin resistant & X. Nemes (Lyon, France) \\
\hline $\mathrm{C} 58 \omega 1$ & Tn5Map in the $3.0 \mathrm{Mb}$ replicon & This study \\
\hline $\mathrm{C} 58 \omega 2$ & Tn5Map in the $2 \cdot 1 \mathrm{Mb}$ replicon & This study \\
\hline $\mathrm{C} 58 \omega 3$ & Tn5Map in pAtC58 $(550 \mathrm{~kb})$ & This study \\
\hline $\mathrm{C} 58 \omega 4$ & $\operatorname{Tn} 5 \mathrm{Map}$ in $\mathrm{p} T \mathrm{i}(200 \mathrm{~kb})$ & This study \\
\hline \multicolumn{3}{|l|}{ Plasmids } \\
\hline ColE1 : : Tn5Map & $\begin{array}{l}\text { Derivative of } \operatorname{Tn} 5 \cos \text { containing the } \\
18 \text { bp I-SceI site }\end{array}$ & Hiller et al. (1994) \\
\hline pGP704 & $\pi$-dependent suicide vector & Miller \& Mekalanos (1988) \\
\hline pGF2 & pGP704 containing Tn5Map & This study (Fig. 1) \\
\hline
\end{tabular}


markers. Details of migration conditions are given in the figure legends.

Southern blots and hybridization. Southern blots of PFGE agarose gels were prepared using nylon membranes (Boehringer Mannheim) by vacuum blotting using a VacuGene XL Blotting System (Pharmacia LKB) with $0.4 \mathrm{M} \mathrm{NaOH}$ as the eluant. Probes were labelled by a non-isotopic method (Digoxigenin DNA labelling kit, Boehringer Mannheim). Non-digested 2:1 $\mathrm{Mb}$ replicon probe was purified by Gene Clean II (Bio-101) after separation in low-melting-temperature agarose (Seaplaque) and then labelled by the same method.

\section{RESULTS}

\section{Construction of pGF2}

ColE1 :: Tn5Map, a derivative of ColE1:: $\operatorname{Tn} 5 \cos$ (Zuber \& Schumann, 1991) containing the 18 bp I-SceI recognition site inserted into the unique Bam $\mathrm{HI}$ site, was available (Hiller $e t$ al., 1994). To facilitate the transfer of Tn5Map to a wide range of bacterial species, it was first subcloned into the suicide vector pGP704 (Miller \& Mekalanos, 1988). This plasmid has the R6K origin of replication and the oriT sequence from RP4. The R6K origin requires for its function the $\mathrm{R} 6 \mathrm{~K} \pi$ protein encoded by the pir gene, which can be provided in trans. A $7541 \mathrm{bp}$ fragment containing Tn5Map was excised from ColE1:: Tn 5Map by first linearizing the plasmid with Alw44I, filling in the overhangs with Klenow enzyme, and then recutting with $E c o$ RI. The 7541 bp fragment was ligated into pGP704, which had been digested with EcoRI and SmaI, resulting in pGF2 (Fig. 1). The permissive host

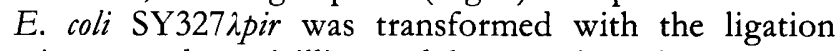
mixture and ampicillin- and kanamycin-resistant transformants were selected. pGF2 was then transferred to $E$. coli SM10 $\lambda$ pir, which provides the RP4 tra functions, for conjugation experiments.

\section{Delivery of Tn5Map by conjugation}

pGF2 was transferred by conjugation from $E$. coli

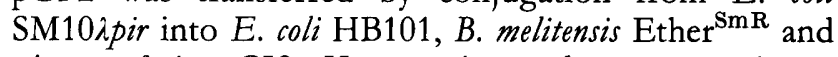
$A$. tumefaciens C58. Kanamycin- and streptomycin-resistant exconjugants were selected. Undigested DNA from individual clones was separated by PFGE, and tested for the presence of Tn5Map by hybridization using labelled ColE1 : : Tn5Map as probe (Fig. 2). E. coli HB101 and $B$. melitensis possess, respectively, one and two circular chromosomes which migrate as faint bands in PFGE. Hybridization showed the presence of $\operatorname{Tn} 5 \mathrm{Map}$ in the transconjugants. Eight $B$. melitensis transconjugant clones were studied: two carried the Tn5Map on the $1.1 \mathrm{Mb}$ chromosomes, while the others carried it on the $2.2 \mathrm{Mb}$ chromosome (data not shown). None of the clones had $\operatorname{Tn} 5$ simultaneously in both chromosomes. Separation of the two large replicons of $A$. tumefaciens requires long pulse times: the faint band corresponded to the $3 \mathrm{Mb}$ circular chromosome and the intense band to the $2.1 \mathrm{Mb}$ linear chromosome. Two faint bands, corresponding to the cryptic circular plasmids pAtC58 $(550 \mathrm{~kb})$ and the tumour-inducing plasmid pTi $(200 \mathrm{~kb})$, were separated using shorter pulses. The three circular replicons were visible only when plugs containing a high DNA con-

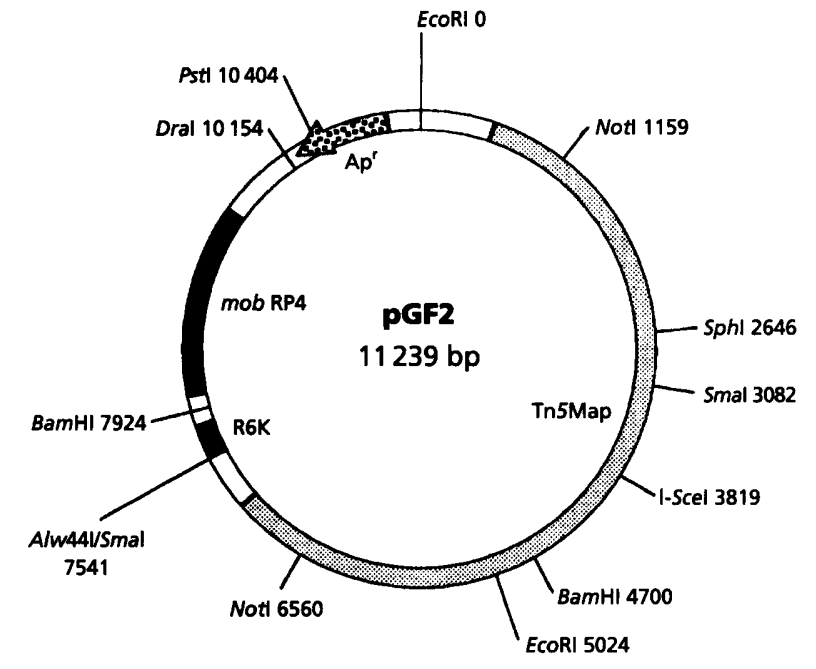

Fig. 1. Structure of plasmid pGF2.

centration $(5 x)$ were used. At this concentration, the $2 \cdot 1 \mathrm{Mb}$ linear chromosome migrated as a thick and intense band of DNA. Eleven $A$. tumefaciens transconjugant clones were studied: one of them carried the $\operatorname{Tn} 5$ on the $2 \cdot 1 \mathrm{Mb}$ chromosome, one on the $550 \mathrm{~kb}$ plasmid, one on the $200 \mathrm{~kb}$ plasmid and eight on the $3.0 \mathrm{Mb}$ chromosome. Four transconjugants with Tn $5 \mathrm{Map}$ integrated in each of the four replicons were kept for further study.

\section{Digestion of genomic DNA with I-Scel}

Conditions for the I-SceI digestion of bacterial genomes in agarose plugs were optimized using $B$. melitensis; the presence of two circular replicons, one without a I-SceI site, allowed the assessment of the levels of non-specific activity. The conditions described in Methods gave optimal results. Longer digestion times increased the levels of non-specific degradation of the DNA. This nonspecific degradation was caused either by the I-SceI enzyme or by contaminants in the enzyme preparation. No non-specific degradation was seen when plugs were incubated in TE buffer or reaction buffer without the enzyme (data not shown). Since no discrete new fragments appeared on prolonged incubation, it is unlikely that cutting occurred at secondary I-SceI sites, which may occur if suboptimal magnesium concentrations are used (Thierry et al., 1991).

Plugs containing genomic DNA from E. coli HB101 and B. melitensis were digested with I-SceI and compared with non digested controls (Fig. 3). Wild-type HB101 was compared with two clones containing Tn5Map insertions

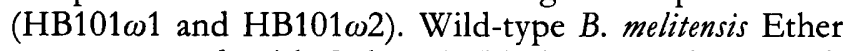
was compared with Ether $\omega 1$ ( $\operatorname{Tn} 5 \mathrm{Map}$ in the $2 \cdot 2 \mathrm{Mb}$ replicon) and Ether $\omega 2$ (Tn5Map in the $1.1 \mathrm{Mb}$ replicon). Digestion with I-SceI specifically increased the intensity of the bands corresponding to the replicons containing Tn5Map, consistent with linearization of circular molecules. Despite optimization of reaction conditions, the increase in the intensity of the bands after digestion was always relatively faint, suggesting partial digestion. To 
(a)

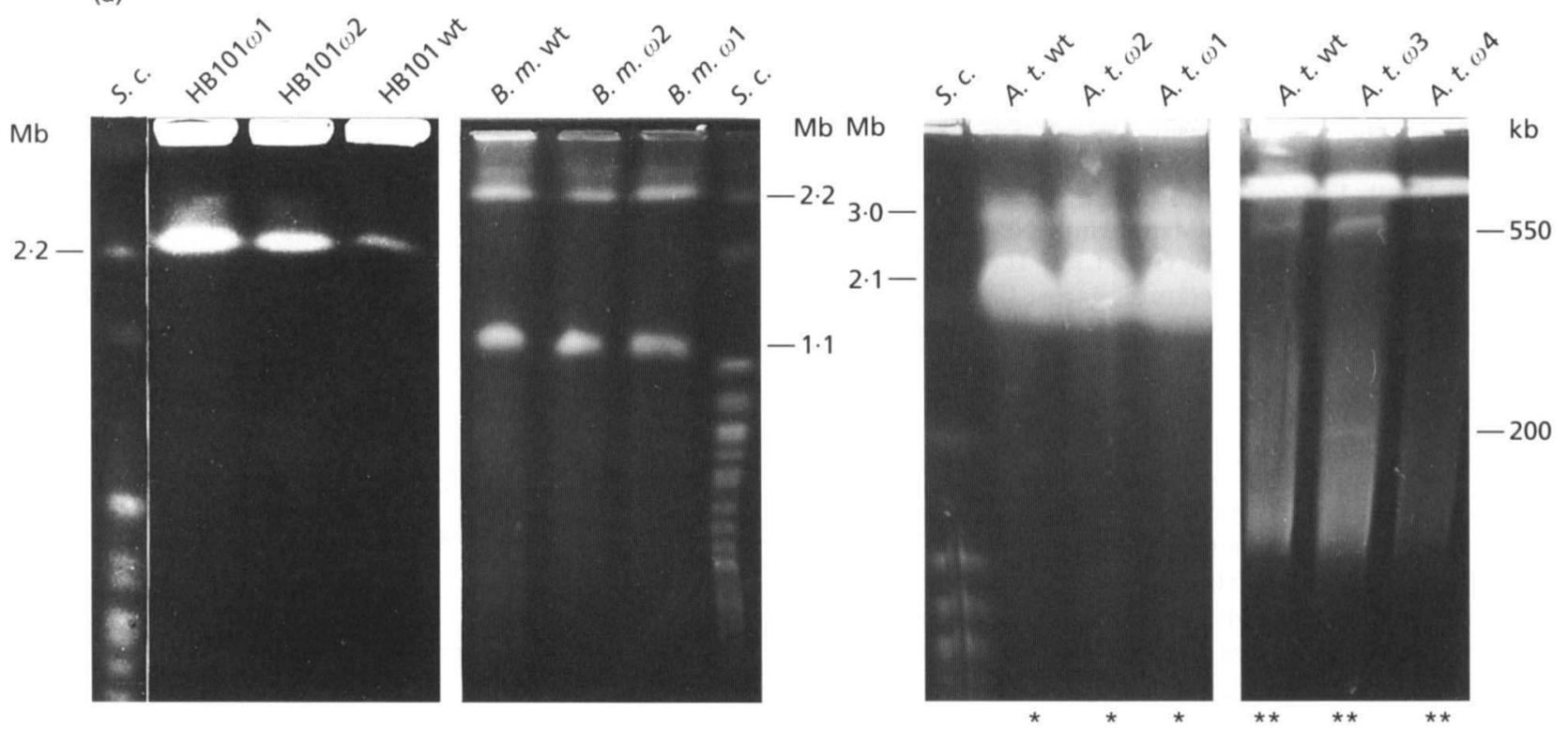

(b)
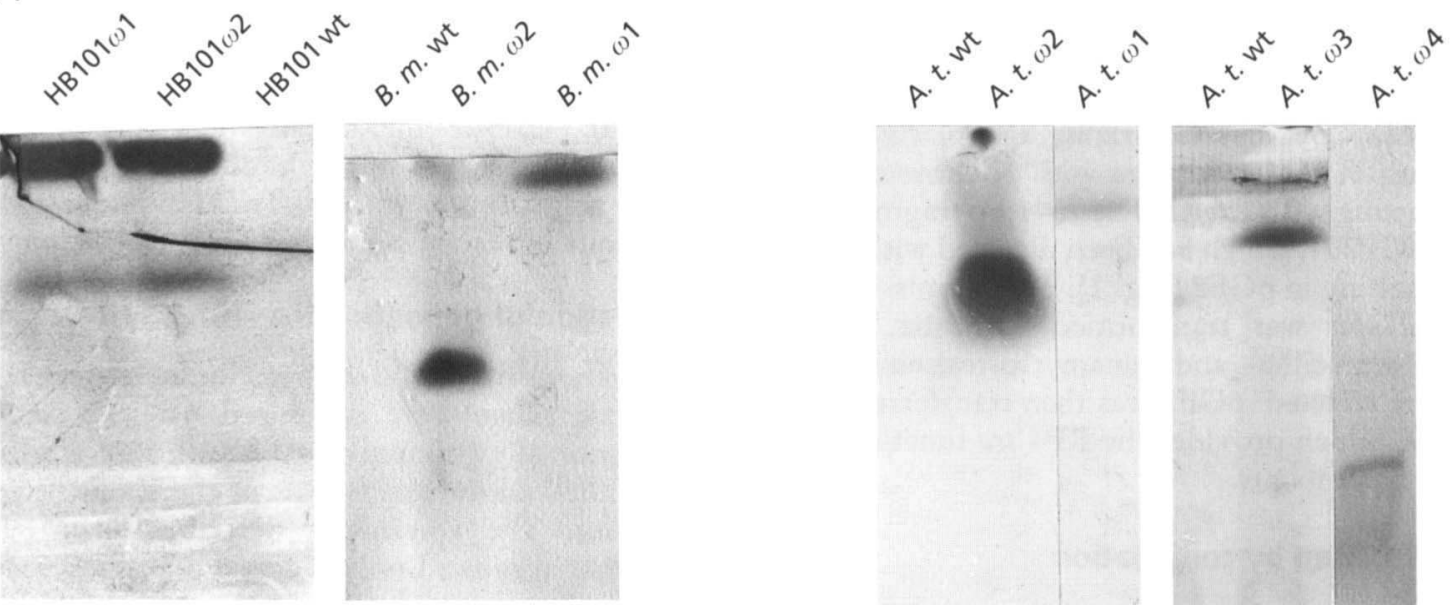

Fig. 2. Tn5Map insertion in E. coli HB101 (HB101), B. melitensis Ether (B. m.) and A. tumefaciens C58 (A. t.) genomes. $\omega$, Strains with Tn5Map insertions (see Table 1); wt, wild-type strains. (a) Ethidium-bromide-stained PFGE gel of $5 \times$ concentrated undigested DNA samples; $S$. cerevisiae (S. c.) chromosomes were used as size markers. (b) Southern transfers of the gels shown in (a) probed with labelled Tn5Map DNA. Migration conditions for $E$. coli and B. melitensis DNAs: pulse ramp 60-130 s at $180 \mathrm{~V}$ in a $0.8 \%$ agarose gel for $24 \mathrm{~h}$; and for $A$. tumefaciens DNA: pulse ramp $90-300 \mathrm{~s}$ at $150 \mathrm{~V}$ in a $0.8 \%$ agarose gel for $45 \mathrm{~h}$ (lanes marked ${ }^{*}$ ) or a fixed pulse of $40 \mathrm{~s}$ for $20 \mathrm{~h}$ at $200 \mathrm{~V}$ in a $1 \%$ agarose gel (lanes marked **).

test this hypothesis a $B$. melitensis Ether $\omega 2$ DNA preparation was first digested by I-SceI, which was then eliminated by proteinase K, and then digested by $S p e I$. The SpeI fragment containing the I-SceI site totally disappeared, giving rise to two new fragments, indicating that the Tn5Map insertion is unique in the B. melitensis genome and that the I-SceI digestion was complete (data not shown).

\section{Analysis of the genome of $A$. tumefaciens C58}

We used digestion by I-SceI to study the genome of $A$. tumefaciens C58. The experiments presented in Fig. 2 identified C58 derivatives $\omega 1$ to $\omega 4$ containing Tn5Map inserted in each of the four replicons. Fivefoldconcentrated plugs were used to visualize the four replicons on ethidium-bromide-stained gels. For the experiments described below, plugs containing $1 \times$ DNA concentration were used. With this concentration only the $2.1 \mathrm{Mb}$ replicon is visible in the PFGE gel. I-SceI-digested and undigested samples were again compared (Fig. 4). I-SceI digestion of C58 $\omega 1$ intensified the $3 \mathrm{Mb}$ band, consistent with linearization of a circular DNA molecule (Fig. 4a).

For the analysis of the $2 \cdot 1 \mathrm{Mb}$ chromosome and the plasmids, shorter pulse times were used. After digestion of C58 $\omega 3$ and C58 $\omega 4$ DNA with I-SceI, bands at $550 \mathrm{~kb}$ 


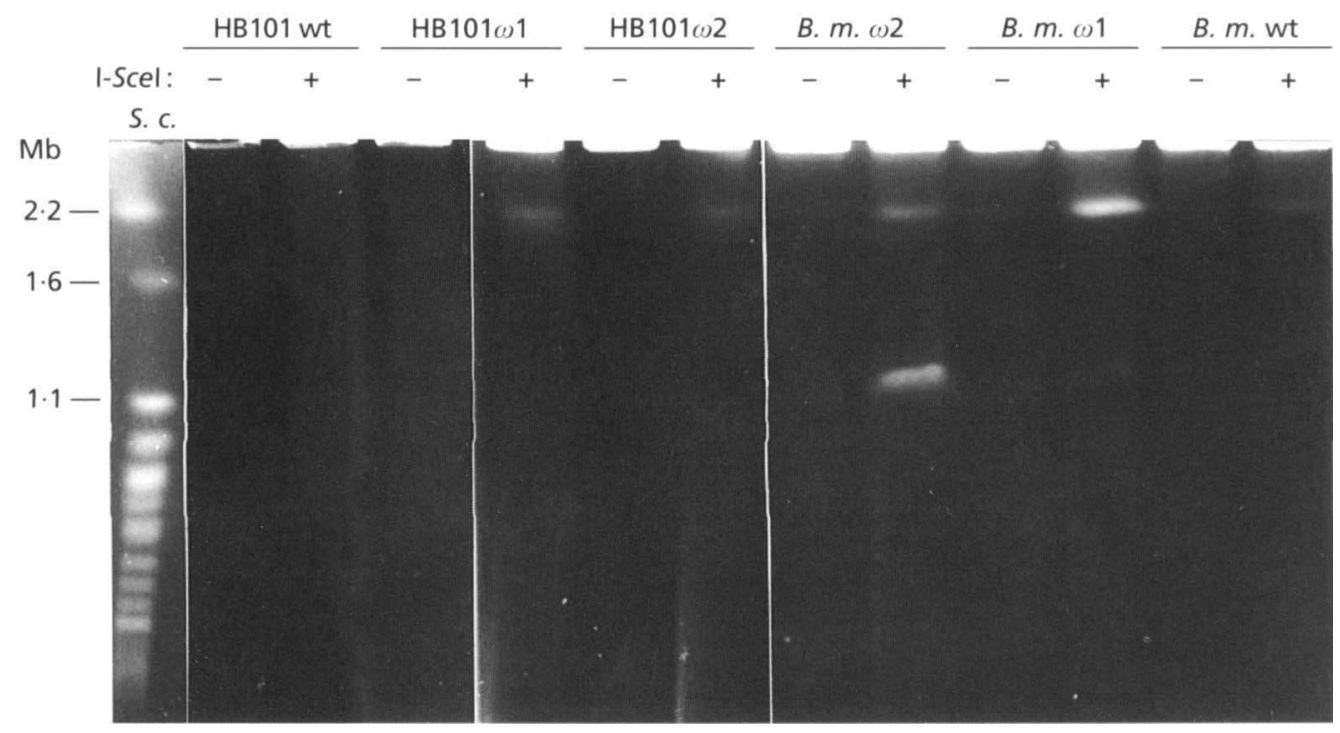

Fig. 3. PFGE gel of I-Scel digests of E. coli (HB101) and B. melitensis Ether (B. m.) DNAs containing Tn5Map (see Table 1) and undigested controls. S. cerevisiae (S. C.) chromosomes were used as size markers. Migration conditions as for Fig. 2.

(a)

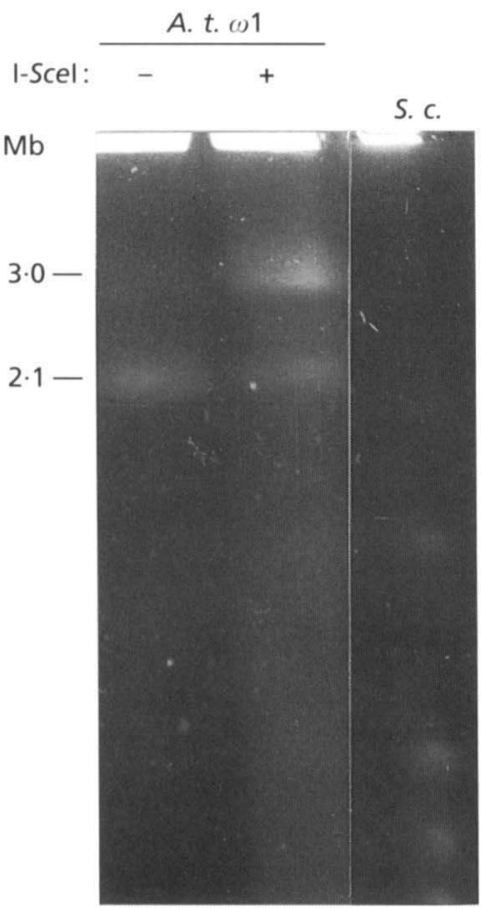

(b)

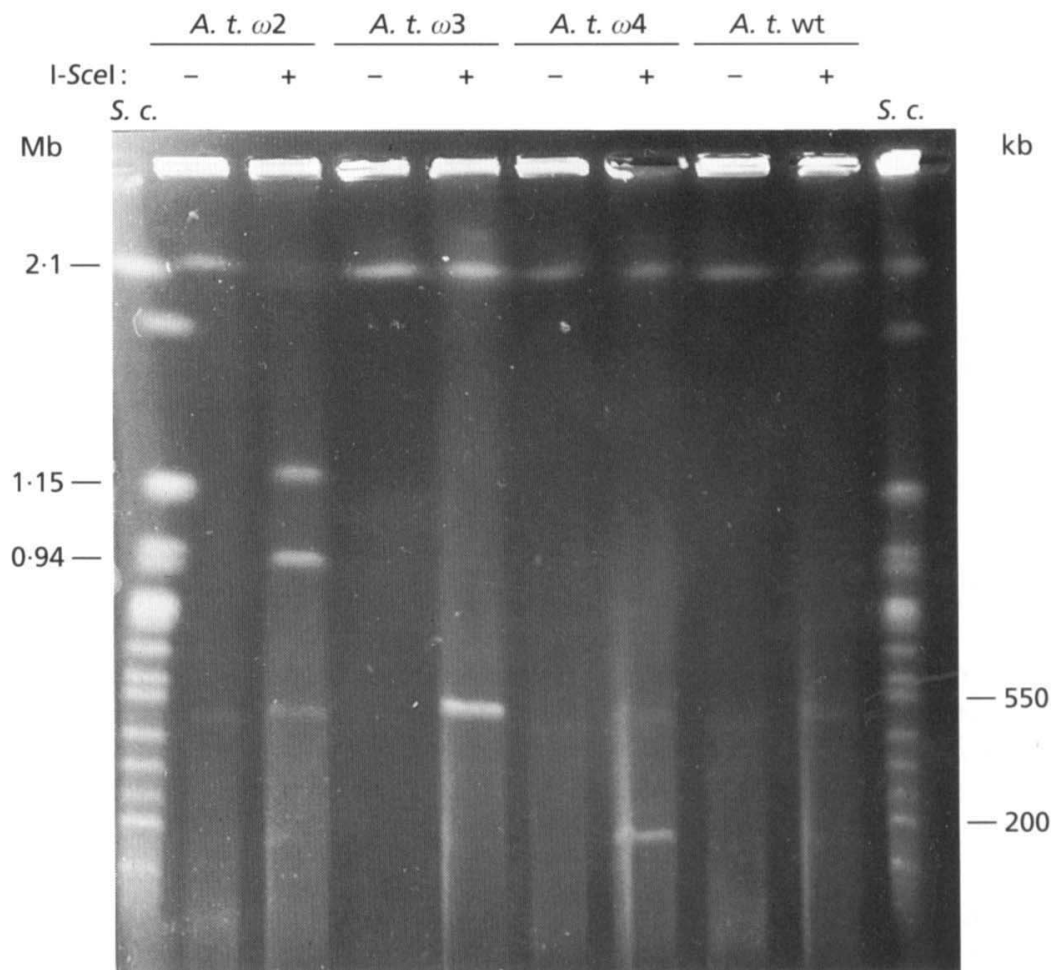

Fig. 4. I-Scel digestion of $A$. tumefaciens C58 DNA containing Tn5Map. (a) C58 $\omega 1$ DNA digested by I-Scel and undigested control. PFGE migration conditions as for Fig. 1 (lanes marked *). (b) C58 2 2, C58 $13, C 58 \omega 4$ and wild-type DNAs digested by I-Scel and undigested controls. Migration conditions were: pulse ramp 60-130 s at $180 \mathrm{~V}$ in a $0.8 \%$ agarose gel for $24 \mathrm{~h}$. $S$. cerevisiae (S. c.) chromosomes were used as size markers in both (a) and (b).

and $200 \mathrm{~kb}$, respectively, appeared, consistent with the linearization of the circular molecules corresponding to the large cryptic plasmid pAtC58 and the tumourinducing plasmid pTi (Fig. 4b).
C58 22 carries Tn5Map in the $2 \cdot 1 \mathrm{Mb}$ replicon. Digestion of wild-type C58 DNA with I-SceI did not alter the intensity or the apparent size of the $2 \cdot 1 \mathrm{Mb}$ replicon. Digestion of C $58 \omega 2$ DNA with I-SceI cleaved the $2 \cdot 1 \mathrm{Mb}$ 


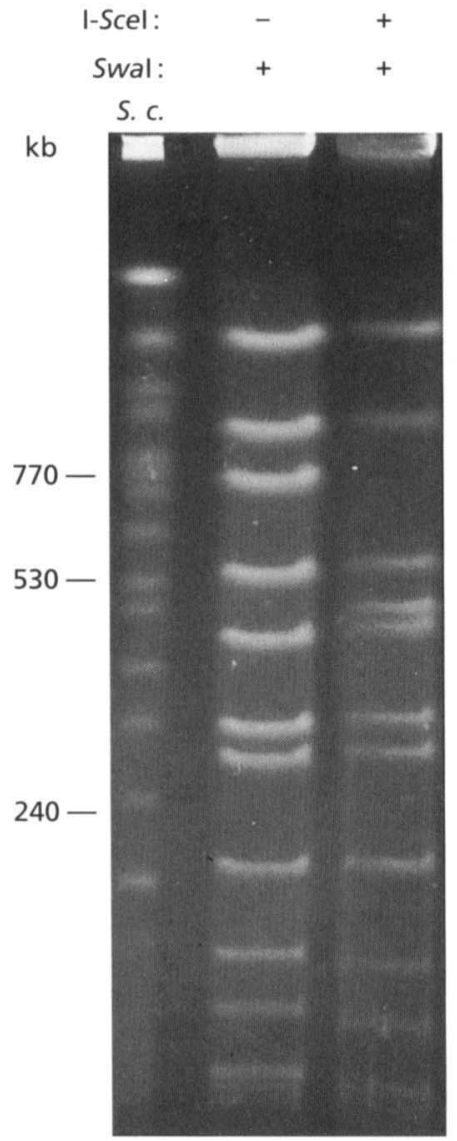

(a)

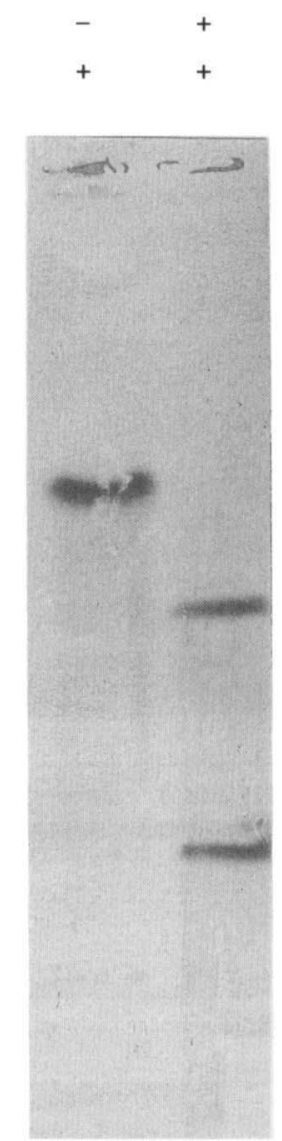

(b)

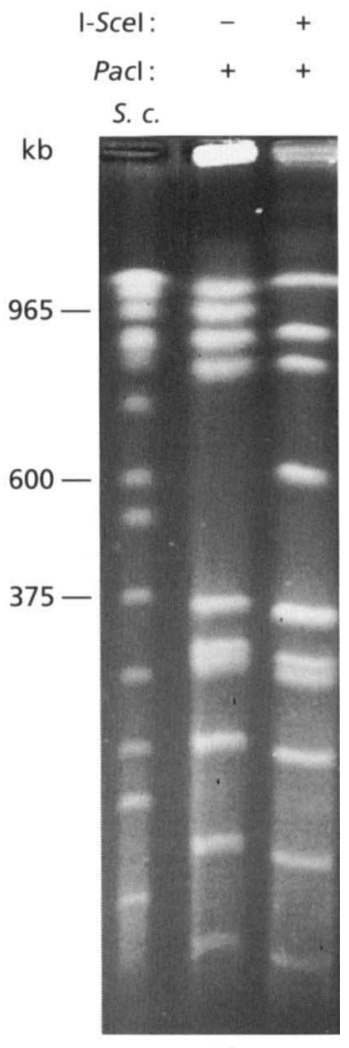

(c)

Fig. 5. Demonstration that the $A$. tumefaciens $\mathrm{C} 58 \omega 2$ genome contains a single Tn 5 Map insert. (a) Ethidium-bromide-stained PFGE gel; comparison of Swal and Swal/I-Scel digestion. (b) Southern blot of the gel shown in (a) probed with labelled Tn5Map. (c) Ethidium-bromide-stained PFGE gel; Pacl/1-Scel-digested C58 $\omega 2$ compared to Pacl-digested C58 $\omega 2$. DNA was electrophoresed in an $1 \%$ agarose gel with two pulse ramps, $10-30 \mathrm{~s}$ for $15 \mathrm{~h}$ and $60-150 \mathrm{~s}$ for $30 \mathrm{~h}$ at $150 \mathrm{~V}$. S. cerevisiae (S. c.) chromosomes were used as size markers in (a) and (c).

band and produced new fragments of $1150 \mathrm{~kb}$ and $940 \mathrm{~kb}$ (Fig. 4b), consistent with the presence of a single I-SceI site in a linear molecule of $2 \cdot 1 \mathrm{Mb}$. A probe prepared from gel-purified $2 \cdot 1 \mathrm{Mb}$ replicon hybridized to the $2 \cdot 1 \mathrm{Mb}$ bands from both wild-type and C58 22 DNAs and also hybridized with the $1150 \mathrm{~kb}$ and $940 \mathrm{~kb}$ fragments, confirming their origin (data not shown).

\section{A. tumefaciens $\mathrm{C} 58 \omega 2$ contains a unique Tn5Map insertion in the $2.1 \mathrm{Mb}$ replicon}

Three experiments were performed to confirm that the insertion in the $2 \cdot 1 \mathrm{Mb}$ replicon of $\mathrm{C} 58 \omega 2$ was unique: (1) C58 $\omega 2$ DNA was digested by a rare-cutting endonuclease, SwaI, which does not cleave Tn5Map. The 14 restriction fragments were separated by PFGE, and then probed with Tn5Map (Fig. 5a, b). Only the $770 \mathrm{~kb}$ SwaI-C fragment hybridized. (2) SwaI/I-SceI double digestion cleaved SwaI-C giving two new fragments of $530 \mathrm{~kb}$ and $240 \mathrm{~kb}$, both of which hybridized to Tn 5 Map (Fig. 5a, b). (3) PacI digestion located Tn5Map in the $965 \mathrm{~kb}$ PacI-B band while PacI/I-SceI double digestion produced two new bands of $600 \mathrm{~kb}$ and $375 \mathrm{~kb}$ (the $375 \mathrm{~kb}$ band comigrated with the PacI-E band) (Fig. 5c). All three experiments are consistent with the insertion of a single Tn5Map in the $2.1 \mathrm{Mb}$ replicon of $A$. tumefaciens C58 2 2. Further, a tandem insertion would produce a fragment of at least $6.6 \mathrm{~kb}$, which was not observed. This replicon must therefore be a linear molecule.

\section{DISCUSSION}

The results of this study show that the delivery of a unique I-SceI site to a bacterial genome using a transposon provides a useful new tool for the analysis of genome topology. To test this application we chose three bacterial species with different genomic organizations. Previously, the linearity of the $2.1 \mathrm{Mb}$ chromosome of $A$. tumefaciens C58 was proposed mostly on the basis of indirect arguments by comparison with the PFGE behaviour of the supposedly circular $3.0 \mathrm{Mb}$ chromosome. This view 
was further supported by data from premigration experiments which removed linear DNA from the plug, and by the behaviour of the replicons in PFGE after $\mathrm{X}$-ray irradiation (Allardet-Servent $e t$ al., 1993). The cutting of the $2.1 \mathrm{Mb}$ replicon of $\mathrm{C} 58 \omega 2$ into two fragments by I-SceI in the present study now provides direct proof of its linearity. Furthermore, in the physical mapping experiments using PFGE, the restriction fragments generated by rare-cutting enzymes are put together to form a circle. Most of these experiments still do not rule out a linear chromosome with fixed ends and terminal repeats (which may cause erroneous interpretation of the hybridization results). These arguments emphasize the need to analyse the intact chromosome, or the chromosome cut only once, as we propose. Furthermore, the ability to introduce a unique restriction site in each replicon of $B$. melitensis and $A$. tumefaciens demonstrates directly the existence of several replicons in the genomes of these bacteria.

Several techniques have been described to reduce the number of cleavable sites in eukaryotic and bacterial genomes. Methyltransferase/endonuclease combinations readily give a reduction of the number of cleavable sites, but not necessarily to one (Nelson \& McClelland, 1992; Weil \& McClelland, 1989). Triple helices containing a modified oligonucleotide creating a site for chemical ('artificial nuclease') cleavage (François et al., 1989), protection of a site from methylation using triple helices (Strobel \& Dervan, 1991), DNA-binding proteins ('Achilles' heel cleavage') (Koob \& Szybalski, 1990) or RecA/oligonucleotide/chromosome complex (RecAassisted restriction endonuclease cleavage) (Ferrin \& Camerini-Otero, 1991) have also been used with success. These methods, however, can be applied without modification only to well-studied organisms since they depend upon either nucleotide sequence data and/or the availability of DNA-binding proteins. Similarly, insertion of a site by targeted recombination requires cloned DNA sequences. We chose to insert a unique restriction site using a modified transposon. This approach has already been used by Hanish \& McClelland (1991) and by Wong \& McClelland (1992) to introduce rare but not unique sites. Insertion of a unique I-SceI restriction site by a transposon such as $\operatorname{Tn} 5$ is an attractive procedure since it is rapid, efficient and versatile.

The combination of Tn5Map and I-SceI is a new tool for the study of bacterial replicon topology, since we have been able to introduce this site into several Gram-negative species. This will be a good test for rapidly identifying linear chromosomes and for estimating the number of replicons in the bacterial genomes. Moreover, the insertion of a unique restriction site, with defined flanking sequences, will be useful for the construction of physical maps of circular bacterial genomes by partial digestion. This method has allowed us to rapidly construct restriction maps of the genome of four Brucella species (unpublished results).

\section{ACKNOWLEDGEMENTS}

We thank Daniel Richard and Daisy Schneider for the photography, and Gisèle Bourg for excellent technical assistance.
David O'Callaghan was supported by ' $L$ 'Association Recherche et Partage'.

\section{REFERENCES}

Allardet-Servent, A., Michaux-Charachon, S. Jumas-Bilak, E., Karayan, L. \& Ramuz, M. (1993). Presence of one linear and one circular chromosome in the Agrobacterium tumefaciens C58 genome. $J$ Bacteriol 175, 7869-7874.

Chu, G., Volrath, D. \& Davis, R. W. (1986). Separation of large DNA molecules by contour clamped homogeneous electric fields. Science 234, 1582-1585.

Cole S. T. \& Saint Girons, I. (1994). Bacterial genomics. FEMS Microbiol Rev 14, 139-160.

Ferrin, J. L. \& Camerini-Otero, R. (1991). Selective cleavage of human DNA: RecA assisted restriction endonuclease (RARE) cleavage. Science 254, 1494-1500.

François, J. C., Saison-Behmoaras, T., Barbier, C., Chassignol, M., Thuong, N. T. \& Hélène, C. (1989). Sequence-specific recognition and cleavage of duplex DNA via triple-helix formation by oligonucleotides covalently linked to a phenanthroline-copper chelate. Proc Natl Acad Sci US A 86, 9702-9706.

Hanish, J. \& McClelland, M. (1991). Enzymatic cleavage of a bacterial chromosome at a transposon-inserted rare site. Nucleic Acids Res 19, 829-832.

Hiller, B., Frey, B. \& Schumann, W. (1994). Tn5Map, a transposon for the rapid mapping of restriction sites in plasmids. FEMS Microbiol Lett 115, 2-3.

Hinnebusch, J. \& Tilly, K. (1993). Linear plasmids and chromosomes in bacteria. Mol Microbiol 10, 917-922.

Koob, M. \& Szybalski, W. M. (1990). Cleaving yeast and E. coli genomes at a single site. Science 250, 271-273.

Michaux, S., Paillisson, J., Carles-Nurit, M. J., Bourg, G., AllardetServent, A. \& Ramuz, M. (1993). Presence of two independent chromosomes in the Brucella melitensis $16 \mathrm{M}$ genome. J Bacteriol 175, 701-705.

Miller, V. L. \& Mekalanos, J. J. (1988). A novel suicide vector and its use in construction of insertion mutations : osmoregulation of the outer membrane proteins and virulence determinants in Vibrio cholerae requires toxR. $J$ Bacteriol 170, 2575-2583.

Monteilhet, C., Perrin, A., Thierry, A., Colleaux, L. \& Dujon, B. (1990). Purification and characterization of the in vitro activity of I-SceI, a novel and highly specific endonuclease encoded by a group I intron. Nucleic Acids Res 18, 1407-1413.

Nelson, N. \& McClelland, M. (1992). Use of DNA methyltransferase/endonuclease enzyme combination for megabase mapping of chromosomes. Methods Enzymol 216, 279-303.

Perrin, A., Buckle, M. \& Dujon, B. (1993). Asymmetrical recognition and activity of the I-SceI endonuclease on its site and on intron-exon junctions. EMBO J 12, 2939-2947.

Sambrook, J., Fritsch, E. F. \& Maniatis, T. (1989). Molecular Cloning: a Laboratory Manual. Cold Spring Harbor, NY: Cold Spring Harbor Laboratory.

Schwartz, D. C., Saffran, W., Welsh, J., Hass, R., Goldenberg, M. \& Cantor, C. R. (1983). New technics for purifying large DNAs and studying their properties and packaging. Cold Spring Harbor Symp Quant Biol 47, 189-195.

Sobral, B. W. S., Honeycutt, R. J. , Atherly, A. G. \& McClelland, M. (1991). Electrophoretic separation of the three Rbizobium meliloti replicons. J Bacteriol 173, 5173-5180.

Strobel, S. A. \& Dervan, P. B. (1991). Single-site enzymatic cleavage 
of yeast genomic DNA mediated by triple helix formation. Nature 350, 172-174.

Thierry, A., Perrin, A., Boyer, J., Fairhead, C., Dujon, B., Frey, B. \& Schmitz, G. (1991). Cleavage of yeast and bacteriophage T7 genomes at a single site using a rare cutter endonuclease I-SceI. Nucleic Acids Res 19, 189-190.

Weil, M. D. \& McClelland, M. (1989). Enzymatic cleavage of a bacterial genome at a 10-base-pair recognition site. Proc Natl Acad Sci US A 86, 51-55.
Wong, K. K. \& McClelland, M. (1992). Dissection of the Salmonella typhimurium genome by use of a $\mathrm{Tn} 5$ derivative carrying rare restriction sites. J Bacteriol 174, 3807-3811.

Zuber, U. \& Schumann, W. (1991). Tn 5 cos: a transposon for restriction mapping of large plasmids using phage lambda terminase. Gene 103, 69-72.

Received 23 March 1995; revised 6 June 1995; accepted 12 June 1995. 